Early Warning Systems and Monitoring Solutions

\title{
Earth Dams Risk Management Kura River Basin
}

\author{
$\underline{\text { Vugar Aliyev }}{ }^{1,5}$, Givi Gavardashvili², Adam Ujma ${ }^{3}$, Mikhailo Yatsuk ${ }^{4}$, Emil Gafarov ${ }^{5}$ \\ ${ }^{1}$ AMIR Technical Services LLC, Apsheron district, Djeyranbatan settlement, AZ-0112, Baku, Azerbaijan \\ ${ }^{2}$ Ts. Mirtskhulava Water Management Institute of Georgian Technical University, \\ 60b, I. Chavchavadze Avenue 0179 Tbilisi, Georgia \\ ${ }^{3}$ Czestochowa University of Technology, Faculty of Civil Engineering, \\ Dabrowskiego 69, 42-200 Czestochowa, Poland \\ ${ }^{4}$ Institute of Water Problems and Land Reclamation of NAAS, 37, Vasilkovskaya str., Kyiv, Ukraine, 03022. \\ ${ }^{5}$ Architecture and Construction University of Azerbaijan, 15, Sultanova str., AZ-1073 Baku, Azerbaijan
}

doi: https://doi.org/10.21467/abstracts.93.56

\begin{abstract}
Introduction. Given paper has the objective for modelling of Emergency Warning System for monitoring and managing earthen dams-break due to natural and human-caused hazards in Kura-Basin in Georgia and Azerbaijan. Monitoring systems set in Azerbaijan and Georgia will consist the water level and discharge measurement stations and the geodetic-geotechnical system to control dam physical stability. By the quantity of large dams (height of a dam > $60 \mathrm{~m}$ and power of HPS > $100 \mathrm{MW}$ ) the Kura River basin takes 14th place in the world. There are 8 large dams on Kura River basin. Last of them is Mingecevir earthen dam, which was put into operation in 1953 (The height of dam is $80 \mathrm{~m}$, length $1,550 \mathrm{~m}$ and total capacity of soil $15.6 \mathrm{mln}$ $\mathrm{m}^{3}$ and reservoir with water capacity $16 \mathrm{~km}^{3}$ ). Heavy flooding and/or break one of dams in Georgia is enough for catastrophic "domino" destruction of all downstream dams. Only, in case of Mingecevir dam failure, the flash flood hazards area of downstream valleys, are $8,000 \mathrm{~km}^{2}$ with around $3.5 \mathrm{mln}$ of inhabitants. Therefore, we can ascertain that now, earthen dams and same reservoirs are both a blessing and a curse of Georgia and Azerbaijan.

Special features of the landscape combined with climatic and soil conditions as well as large number and volume of rivers cause unexpected highly hazardous natural disasters in Kura river basin. In recent past floods occurred in Kura River. Rivers of the Kura basin has extremely irregular discharge throughout a year. Ratio of extreme discharge to average discharge level is 1.7-3.0 which makes sometimes difficult to overcome its negative impact. Therefore, cascade of dams were made along Kura River for flood management. This cascade has been built as multi-purpose dams. Its intended purposes are hydropower, flood control, irrigation, etc. to achieve balanced and sustainable development of the country.
\end{abstract}

\section{Last dam-break events in Kura River basin.}

Last dam-break event in Georgia happened in 1987: 11.9 meters dam of Cghneti dam near Tbilisi city destroyed in 1987 May 14. This dam exploited 30 years and it destroyed as a result of continuous heavy rains. 3 persons died during flood. Last dam-break events in Azerbaijan happened in 2010 spring and 2016 autumn: First one, water level of Kura River was rising extremely as a result of long-term heavy rains in 2010 May. The depth of Sarisu Lake near the Kura River, since feeding from Kura River is 2 meters normally, water depth was 7-8 meters in flood period, and some places were 11 meters. Ground water level in coastal fortification of lake was rise, also waves height created in lake was $40-50 \mathrm{~cm}$ that caused its damage. Second of them, water discharge in Goytepe River has increased in the extreme degree in the result of intensive rains in the Djalilabad on the 30 October, 2016, it has damaged $17.5 \mathrm{~m}$ height dam of the water reservoir.

(C) 2020 Copyright held by the author(s). Published by AIJR Publisher in "Abstracts of The Second Eurasian RISK-2020 Conference and Symposium" April 12- 19, 2020, Tbilisi, Georgia. Jointly organized by AMIR Technical Services LLC, Georgian Technical University, Institute of Geography (Kazakhstan) and Russian Institute of Petroleum Geology and Geophysics.

Aij. DOI: 10.21467 /abstracts.93 
The Second Eurasian RISK-2020 Conference and Symposium

Extreme water getting over the dam damaged its low slope. The big damage happened on population and private economy in large areas.

The development of large hydraulic structures such as Mingecevir embankment dam should be undertaken within the broad context of water resources management as a whole. Such infrastructure clearly has an impact on downstream water resources in a wide variety of ways, and similarly, the management of water resources upstream will have an impact on the development under consideration. It is therefore not possible to adequately manage a Mingecevir cascade of dams as an isolated entity - they must be integrated into the management of Kura river basin water resources as a whole. Natural or induced floods are of increasing concern to water managers and civil protection services for three main reasons. Firstly, a continuous and "unconscious" increase of social pressure in the flooding valleys amplifies flood vulnerabilities and consequently natural or induced flood risk. Secondly, the alarming forecasts of the impact of potential climate changes on water resources, in spite of the high uncertainty associated to these forecasts, points out to larger flood hazards. Thirdly, as mentioned above, dam-break induced accidents may occur more frequently due to infrastructure aging.

The development of Transboundary Flood Emergency Warning System is an ideal opportunity to create open dialog and healthy relationships between the Kura river basin organizations of riparian States. A plan for high levels of participation should lead to responsibility and empowerment, which is ideal because of the sustainability factor and the goal of self-perpetuating activities within a Kura River watershed.

The Soviet environmental legacy. All of the embankment dams in Kura River basin in Azerbaijan and Georgia were built in Soviet period, before the independence of these republics. The basic criterion of technical realization of such projects those years was the principle of their minimal cost. Thus issues of strategic risk, ecological safety and other, as a rule, at all did not take seriously. The choice of a building material and construction method of Mingecevir dam and others have been proved by this principle. Separate risk factors for the destruction of earthen dams considered: Probability of terrorist threats and military actions; Earthquakes; Sludge settling of reservoir; Prolonged periods of flooding and failure of upstream dams on the Kura river basin; Animal intrusions and probability of piping

The dams on rivers belong to the critical infrastructure of countries. That is, they form part of functionally related objects, including building objects, devices, installations, crucial for the security of the country and its citizens, and serving to ensure efficient functioning of administration. Therefore, they must be subject to crisis management of countries. The creation of the dam management system on the Kura River should use the world experience of other countries. The latest equipment should be used to test the flow and monitor the technical condition of dams. In assessing the condition of dams and the changes that have occurred in them, as well as sediments at the bottom of dams, 3D scanning technology should be used. To carry out a very large scope, various research and create a monitoring system for dams on the Kura River, it would be advisable to use funds from foreign organizations financing activities aimed at improving the security of such facilities. 